\title{
The Construction and Validation of the Revised Arabic Scale of Obsession-Compulsion (ASOC)
}

\author{
Ahmed M. Abdel-Khalek* \\ Department of Psychology, Alexandria University, Alexandria, Egypt
}

Received: 制April 28, 2018; Published: 㘹 May 10, 2018

*Corresponding author: Ahmed M. Abdel-Khalek, Department of Psychology, Faculty of Arts, Alexandria University, Alexandria, Egypt

\begin{abstract}
Background: Recent surveys estimated that prevalence rates of obsessive-compulsive disorder (OCD) were more than those estimated by earlier surveys. Moreover, in the general non-clinical population, many studies found high incidence of obsessions and compulsions (OC).
\end{abstract}

Objective: To develop and validate a revised version of the Arabic Scale of Obsession-Compulsion (ASOC) as a trait scale, suitable for research studies.

Methods: A Sample of 150 non-clinical undergraduates was recruited. The latest version of the revised ASOC is comprised of 20 short statements, plus five filler items. Two subscales of OC were used as criteria from the MMPI, and the Symptom Checklist, (SCL), as well as the Obsessive-Compulsive Inventory (OCI).

Results: Cronbach alpha reliabilities reached .882 (men), .910 (women), and .897 (total group). The correlation coefficients of the ASOC with the MMPI, SCL, and OCI scales were .759, .783, and .885, respectively. A principal component analysis retained one high-loaded factor labeled "Obsession-compulsion". The loading of the ASOC onto this factor was .948, indicating very high factorial validity.

Conclusion: The ASOC has good psychometric characteristics, i.e., high internal consistency and concurrent and factorial validities.

Keywords: Arabic Scale of Obsession-Compulsion; Minnesota Multiphasic Personality Inventory; Symptom Checklist; ObsessionCompulsion Inventory; Reliability; Validity; Egypt

Abbreviations: OCD: Obsessive-Compulsive Disorder; OC: Obsessions and Compulsions; ASOC: Arabic Scale of ObsessionCompulsion; MMPI: Minnesota Multiphasic Personality Inventory; SCL: Symptom Checklist; OCI: Obsessive-Compulsive Inventory; DSM: Diagnostic and Statistical Manual of Mental Disorders

\section{Introduction}

The fourth edition of the Diagnostic and Statistical Manual of Mental Disorders (DSM) classified obsessive-compulsive disorder (OCD) under the category: anxiety disorders. However, more recently, in the fifth edition of the DSM [1], OCD has become the first item in a separate category under the name: Obsessive-Compulsive and Related Disorders. It includes OCD, body dysmorphic disorder, hoarding disorder, trichotillomania, excoriation, substance/ medication - induced obsessive-compulsive and related disorders.

OCD is characterized by the presence of obsessions and/or compulsions. Obsessions are recurrent and persistent thoughts, urges, or images that are experienced as intrusive and unwanted, whereas compulsions are repetitive behaviors or mental acts that an individual feels driven to perform in response to an obsession or according to rules that must be applied rigidly (p. 235) [1]. In earlier surveys, the prevalence of OCD in the general population was $0.5 \%$ [2], but more recent surveys estimated the 12 -month 
prevalence of OCD in the United States at $1.2 \%$, with a similar prevalence internationally (1.1\% - $1.8 \%$ ) [1]. In Egypt, a study in 1991 showed the incidence of OCD at $2.3 \%$ [3].

On the other hand, a number of research studies indicated the high incidence of obsession (about $80 \%$ ) in the general nonclinical population, as well as the similarity between normal and pathological obsessions [4-6]. Furthermore, the form and content of the obsessions did not differ between normals and OCD patients. Nevertheless, obsessions of patients occur more frequently, last longer, are more intense, disrupt their lives, arouse more discomfort and resistance, and are difficult to dismiss. The same results applied well to compulsions [4]. Therefore, it seems suitable to consider normal and abnormal obsessions and compulsions (OC) on the basis of the quantitative and dimensional approach.

Egypt, as a developing country, like the rest of the Arab countries, is in great need of psychological tests and questionnaires. In 1992, Abdel-Khalek [7] developed the Arabic Scale of ObsessionCompulsion (ASOC), and in 1998, he developed an equivalent English version of this scale [8]. Several studies were published using this English version [9-16], as well as the Arabic form. Moreover, a Spanish form of the scale is available [17].

Twenty-six years have passed since the publication of the Arabic form of the ASOC. Furthermore, its author found some aspects to be improved which are as follows: (a) the first version consists of too many items (32), a short form is badly needed to avoid the participant's boredom and carelessness, in answering the questionnaire and to save their time, (b) some items consist of long statements and it is preferable to use short ones, (c) the response alternatives were dichotomous (Yes/No), while the Likert format has psychometric advantages, and (d) the old scale contained $28 \%$ negative items scored as "No" indicating non OC behavior (e.g., I do not like strict discipline and too much accuracy). Some authors stated that negatively worded items often turn out to be harder to understand or more complicated to answer than positively worded ones [18]. Other authors concluded that negatively worded items impair response accuracy [19], so there seems to be a need to use only positively worded items. The aim of the present research was to develop a revised version of the ASOC as a trait scale to be used in research in the general population, and to estimate its psychometric properties.

\section{Material and Methods}

\section{Participants}

A convenience sample of 150 undergraduates enrolled in different faculties in Alexandria University, Alexandria, Egypt took part in this study (74 men; 76 women). Their ages ranged from 17 to 25 years $(M$ age $=20.95, S D=2.01)$. They were nonpaid volunteers, and were neither classified as clinical cases nor diagnosed institutionalized patients, but, rather were presumably healthy individuals. That is, they were not selected from hospitals or clinics. However, no psychiatric assessment was conducted to support that these participants had no mental illness.

\section{Psychometric Scales}

\section{The Arabic Scale of Obsession-Compulsion (ASOC)}

Construction of the revised scale: The 32 items of the original ASOC were shortened and the negative wording changed to positive to avoid the problem of double negatives. Five new items were added. The 37 statements were brief and written in standard, modern, and simple Arabic. A sample of 150 undergraduates responded to the 37 items based on a 5-point Likert scale. Then, the corrected item-rest-of-test score correlations (i.e., the itemremainder correlations) were computed. All the correlations were statistically significant. Since the aim was to develop a 20 item scale, the items with highest correlations with the remainder were retained.

Response alternatives: Each item of the ASOC is answered on a 4-point Likert-type scale : 1 (No), 2 (Some), 3 (Much), and 4 (Always). The total score could range from 20 to 80, with higher scores indicating higher OC. The ASOC was intended to be used as a trait and not a state scale, inasmuch as the instructions use the term "in general".

Response set: Since negatively worded items show psychometric problems, and since many persons face difficulty in responding to them, particularly the double negative, it was decided to use only positively worded statements. To control acquiescence response bias and other response sets, to some extent, five filler items were randomly added with a normal, positive, and nonOCD content. These items were not considered in the total score. Examples of the filler items are as follows: "I am happy with my life style", "I feel optimistic about the future", and "I am satisfied with myself".

Scoring: The ASOC consists of 25 items but five of them are fillers and must be excluded from the computation of the total score (Items number: 1, 5, 12, 17, and 20). The remaining 20 items are positive indicators of OC. The algebraic sum of a participant's scores on the 20 items represents his/her total score on the ASOC.

\section{The MMPI Psychasthenia Scale}

The Minnesota Multiphasic Personality Inventory (MMPI) Psychasthenia Scale [20] was used to test the concurrent validity of the ASOC.

\section{The SCL-90-R Obsessive-Compulsive Scale}

The Symptom Checklist-90-revised (SCL-90-R) [21] OC subscale was administered to estimate the validity of the ASOC.

\section{Obsessive-Compulsive Inventory}

The OCI [22] was also used to estimate the concurrent validity of the ASOC. 


\section{Procedure}

The four scales were administered anonymously in Arabic to participants in group sessions of a small number of participants in their classrooms, during regular university hours. The time of administration ranged from 15 to 30 minutes. Participants provided verbal agreement to offer themselves as subjects after the objectives of the study were briefly outlined. Assurances were made that anonymity would be maintained. Graduates studying for a Master's Degree in Psychology carried out the administration of the scales.

\section{Results}

\section{Reliability}

The corrected item-total correlations of the 20 ASOC items ranged between 0.26 and 0.71 . Cronbach's alphas were 0.882 (men), 0.910 (women), and 0.897 (total sample), indicating high internal consistency.

\section{Concurrent Validity}

The Pearson product-moment correlation coefficients were computed between the four aforementioned OC scales. Table 1 shows that all the correlations are statistically significant and positive. The correlations between the ASOC and the other scales ranged between .759 and .885 , indicating the concurrent validity of the ASOC.

\section{The Factorial Validity of the ASOC}

The correlation matrix of the last-mentioned four OC scales was subjected to a principal component analysis. The Kaiser criterion of eigen value $\geq 1.0$, and the scree test followed to determine the number of factors to be retained [23]. Both criteria defined one high-loaded factor, accounting for a high percentage of the explained variance (82.1\%), and labeled "Obsession- compulsion". The loading of the ASOC onto this factor was .948, indicating its high factorial validity (Table 1) and (Figure 1).

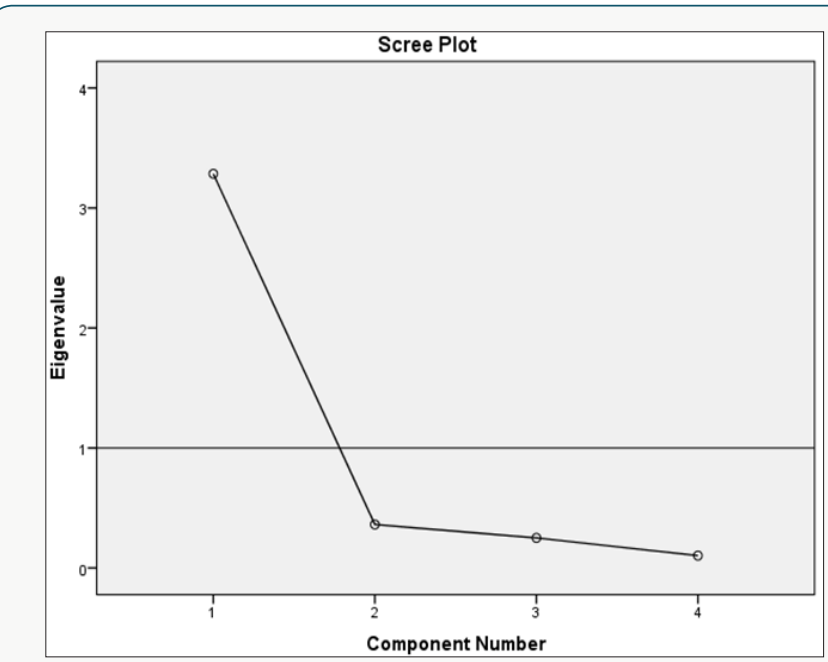

Figure 1: Scree plot for the OC factor.
Table 1: Pearson correlation coefficients, the extracted first factor, and the communalities $\left(\mathrm{h}^{2}\right)$.

\begin{tabular}{|c|c|c|c|c|c|c|}
\hline \multirow{2}{*}{ Scales } & \multicolumn{4}{|c|}{ Correlations* } & \multirow{2}{*}{ Factor I } & \multirow{2}{*}{ h2 } \\
\hline & ASOC & MMPI & SCL-90-R & OCI & & \\
\hline 1. ASOC & - & & & & 0.948 & 0.898 \\
\hline 2. MMPI & 0.759 & - & & & 0.871 & 0.759 \\
\hline 3. SCL & 0.783 & 0.741 & - & & 0.896 & 0.803 \\
\hline 4. OCI & 0.885 & 0.670 & 0.728 & - & 0.908 & 0.824 \\
\hline \multicolumn{6}{|c|}{ Eigen Value } & 3.285 \\
\hline \multicolumn{6}{|c|}{$\%$ Variance } & 82.133 \\
\hline
\end{tabular}

*All correlations $p<0001$

\section{Preliminary Descriptive Statistics}

Mean $(M)$ and standard deviation $(S D)$ were computed for men and women separately. Then, the $t$-test for the difference between the mean scores of men and women was computed. Fore men, $M=$ 51.32, $S D=14.09$, and women, $M=49.95, S D=16.15$ ( $t=.814$, n.s. $)$.

\section{The English version of the ASOC}

The Arabic form of the ASOC was translated into English by a competent psychologist. This translation was revised and edited by the present researcher. Then, a back translation [24, 25] of the scale items from English into Arabic was performed as a check on the adequacy of the Arabic into English translation. This preliminary English translation was given to an Arab linguist competent in both languages to translate back into Arabic. The original Arabic form was compared with the back translation form for similarity. Few corrections were made. Two American Professors edited the English version (see the Appendix).

\section{Discussion}

Recent studies indicated that the prevalence rates of OCD are higher than those of earlier estimations, i.e., more than double the previous prevalence rates $[1,2]$. Following a similar pattern, empirical studies found that OC symptoms are prevalent among the non-clinical population [4-6]. For these reasons and others, researches on OCD and OC using clinical cases and participants from the general non-clinical population have burgeoned. However, the vast majority of the studies in this endeavor were carried out mainly in Western countries. Researches on the third world, including Arab countries, are scarce. There is ample need to carry out studies using samples from these under-studied and underrepresented countries.

Measurement and assessment in this field are very important. The Arabic Scale of Obsession-Compulsion (ASOC) has three forms: Arabic, English, and Spanish. The Arabic form was published 26 years ago and some improvements seem mandatory. The present study successfully fulfilled its objective i.e., to construct and validate the revised ASOC.

The revised ASOC has specific ameliorations. That is, shorter 
(20 items plus five fillers vis-a-vis 32 items in the original form). Some authors studied the length of personality inventories and concluded that the short form is more favorably evaluated [26]. In three studies, Burisch [27] maintained that short scales were as valid on the average as long scales. He added [28] that lengthening a scale beyond some point can actually weaken its validity. In a similar vein, the items (statements) of the revised ASOC have become shorter, so it takes less time to administer compared to the original scale. A reduction of administration time can be considered as an advantage to the enhancement of the cost-effectiveness of the revised scale, particularly in research projects with loaded test batteries.

Another advantage of the revised ASOC is not using the negatively worded items. Many participants face difficulties in responding to these items, especially when seeing double negatives. Moreover, the psychological meaning of the negatively worded items are, ipso facto, not the exact meaning of the opposite of the positively worded items, e.g., "I am depressed" is not the contrary of "I am happy". Baumeister et al. [29] wrote a paper entitled: "Bad is stronger than good". They stated that items describing negative emotions tend to evoke much stronger responses than items describing positive emotions. People tended to under-estimate the frequency of positive affect, but not negative affect. They concluded that bad emotions generally produce more cognitive processing and have other effects on behavior that are stronger than positive emotions. To solve the problem of the negatively worded items, and to partially control the response set, all the items of the ASOC have become positive indicators of OC, and five filler items referring to mental health were randomly added to the scale as distracters. Furthermore, the revised ASOC has good psychometric characteristics.

Regarding the reliability, the alphas were 0.88 and 0.91 for men and women, respectively, indicating high internal consistency. References of psychometrics [30,31] suggested that reliabilities approaching 0.70 or higher are acceptable for research. The present results are higher than that limit. Furthermore, the ASOC has high concurrent validity and very high factorial validity.

\section{Conclusion}

The revised ASOC has many advantages, i.e., brevity of scale, short and simple statements, no use of negatively worded items, use of fillers as distracters, avoidance of double negatives, and use of multiple response alternatives. Moreover, it has good internal consistency, high concurrent validity, and very high factorial validity, as well as the availability of two equivalent Arabic and English forms.

\section{Limitations}

Despite the good psychometric properties of the ASOC, the scale is in need of: computing the test-retest reliability, carrying out exploratory and confirmatory factor analysis, assessing its associations with the Big Five personality factors, and determining normative values for a large sample of different ages. Further, the English version of the ASOC merits investigation using an Englishspeaking sample. These points are subjects for further investigation.

\section{Acknowledgement}

I would like to thank Dr. Jimmy Beshai, Ph. D. and Mrs. Suzan Adel for their assistance in the back translation of the scale. Many thanks to Professor David Lester, Richard Stockton University, and Professor Robert Neimeyer, University of Memphis, for their editing the English version of the scale. I also thank Master students , Yosra Kamal, Yomna Kamal, Suzan Adel, Shereen Alsiofy, and Mohammad Anwar, for their help in the administration of the scale.

\section{References}

1. American Psychiatric Association (2013) Diagnostic and statistical manual of mental disorders ( $5^{\text {th }}$ ed.). American Psychiatric Press, Washington DC, USA.

2. Templer DI (1972) The obsessive-compulsive neurosis: Review of research findings. Comprehensive Psychiatry 13(4): 375-383.

3. Okasha A, Saad A, Khalil AH, Seif El Dawla A, Yehia N (1994) Phenomenology of obsessive-compulsive disorder: A transculture study. Comprehensive Psychiatry 35(3): 191-197.

4. De Silva P, Rachman S (1992) Obsessive-compulsive disorder: The facts. Oxford University Press New York, New York USA.

5. Salkovskis PM, Harrison JC (1984). Abnormal and normal obsessions: A replication. Behavior Research and Therapy 22(5): 549-552.

6. Sanavio E (1988) Obsessions and compulsions: The Padua Inventory. Behavior Research and Therapy 26(2): 169-177.

7. Abdel-Khalek AM (1992) Manual of the Arabic Scale of ObsessionCompulsion. Anglo-Egyptian Bookshop, Cairo, Egypt, [in Arabic].

8. Abdel-Khalek AM (1998) The development and validation of the Arabic Obsessive Compulsive Scale. European Journal of Psychological Assessment 14(2): 146-158.

9. Abdel-Khalek AM, Lester D (1998) Reliability of the Arabic ObsessiveCompulsive Scale in Kuwaiti and American students. Psychological Reports 83(3 pt 2): 1470.

10. Abdel-Khalek AM, Lester D (1999) Obsession-compulsion in college students in the United States and Kuwait. Psychological Reports 85(3 pt 1): 799-800.

11. Abdel-Khalek AM, Lester D (1999) Criterion-related validity of the Arabic Obsessive-Compulsive Scale in Kuwaiti and American students. Psychological Reports 85(3 Pt 2): 1111-1112.

12. Abdel-Khalek AM, Lester D (2000) Obsession-Compulsion, locus of control, depression, and hopelessness: A construct validity of the Arabic Obsessive-Compulsive scale in American and Kuwaiti students. psychological Reports 86(3 Pt 2): 1187-1188.

13. Abdel-Khalek AM, Lester D (2002) Factorial validity of the Arabic Obsessive-Compulsive Scale in two cultures. Psychological Reports 90 (3 Pt 1): 869-870.

14. Abdel-Khalek AM, Lester D (2002) Convergent and discriminant validity of the Arabic Obsessive-Compulsive Scale for Kuwaiti and American college students. Psychological Reports 90(3 Pt 2): 1261-1262.

15. Abdel-Khalek AM, Lester D, Barrett P (2002) The factorial structure of the Arabic Obsessive-Compulsive Scale in Kuwaiti and American college students. Personality and Individual Differences 33(1): 3-9. 
16. Abdel-Khalek AM, Lester D (2003) Obsession-compulsion and its relation to age and sex in Kuwaiti and American students. Psychological Reports 93(3 Pt 1): 803-804.

17. Abdel-Khalek AM, Gomez-Benito J, Tomás-Sábado J, Guilera-Ferré G (2015) The psychometric parameters of the Spanish form of the Arabic Obsessive-Compulsive Scale (S-AOCS). Pyrex Journal of Psychology and Counseling 1(1): 1-7.

18. Carver CS, Scheier MF (2000) Perspectives on personality (4th ed.). Allyn \& Bacon, Boston, Massachusetts, USA.

19. Schriesheim CA, Hill KD (1981) Controlling acquiescence response bias by item reversals: The effect on questionnaire validity. Educational and Psychological Measurement 41(4): 1101-1114.

20. Butcher JN, Graham R, Ben Porath YS, Tellegen AM, Dahlstrom WG Kaemmer B (2001) MMPI-2: Manual for administration and scoring (Rev. ed.). University of Minnesota Press, Minneapolis, Minnesota USA.

21. Derogatis IR (1994) SCL-90-R: Administration, scoring, and procedures manual ( $3^{\text {rd }}$ ed.). National Computer Systems, Minneapolis, USA.

22. Foa EB, Kozak MJ, Salkovskis PM, Coles ME, Amir N (1998) The validation of a new obsessive compulsive disorder scale: The ObsessiveCompulsive Inventory. Psychological Assessment 10(3): 206-214.

23. SPSS (2009) SPSS: Statistical data analysis: Base 18.0, Users guide. SPSS Appendix: The ASOC

Respondent Age: Respondent Sex: Male or Female (circle the appropriate)

Instructions

Please read each of the following statements carefully, and determine how much it describes your feelings and behavior. Indicate how it applies to you in general, by circling one of the following words in front of each statement: No, Some, Much and Always.

\begin{tabular}{|c|c|c|c|c|}
\hline 1-I am happy with my lifestyle. & No & Some & Much & Always \\
\hline 2-Before going to sleep, I check several times to make sure that the doors are closed. & No & Some & Much & Always \\
\hline 3-I keep thinking about particular sentences or words. & No & Some & Much & Always \\
\hline 4- I like strict discipline. & No & Some & Much & Always \\
\hline 5- I feel optimistic about the future. & No & Some & Much & Always \\
\hline 6- Trivial things preoccupy me and dominate my thoughts. & No & Some & Much & Always \\
\hline 7- I wash and clean obsessively. & No & Some & Much & Always \\
\hline 8-My problem is reviewing things repeatedly. & No & Some & Much & Always \\
\hline 9- I count unimportant things. & No & Some & Much & Always \\
\hline 10- Repetitive thoughts press into my mind. & No & Some & Much & Always \\
\hline 11- I like collecting and saving many things. & No & Some & Much & Always \\
\hline 12-Life seems beautiful to me. & No & Some & Much & Always \\
\hline 13- I think of ugly things that I can't talk about. & No & Some & Much & Always \\
\hline 14- Trivial ideas dominate me and keep annoying me for days. & No & Some & Much & Always \\
\hline 15- I have to repeat the same actions such as touching, counting or washing. & No & Some & Much & Always \\
\hline 16- It is difficult for me to make decisions. & No & Some & Much & Always \\
\hline 17- I am satisfied with myself. & No & Some & Much & Always \\
\hline 18- I care about small details. & No & Some & Much & Always \\
\hline 19- I am an obsessive person. & No & Some & Much & Always \\
\hline 20- I feel comfortable and reassured. & No & Some & Much & Always \\
\hline 21- I collect things I don't need. & No & Some & Much & Always \\
\hline 22- I feel compelled to do certain things. & No & Some & Much & Always \\
\hline 23- I have to do things many times to make sure they are accurate. & No & Some & Much & Always \\
\hline 24-I wash my hands more often, or for longer than necessary. & No & Some & Much & Always \\
\hline 25- I repeatedly check doors, windows and drawers. & No & Some & Much & Always \\
\hline
\end{tabular}

Inc, Chicago, Illinois USA

24. Brislin RW (1970) Back translation for cross-cultural research. Journal of Cross-Cultural Psychology 1(3): 185-216.

25. Brislin RW (1980) Translation and content analysis of oral and written material. In HC Triandis and JW Berry (Eds.), Handbook of cross-cultural psychology. Boston Massachusetts, USA: Allyn \& Bacon 2: 389-444.

26. Merrens MR, Richards WS (1973) Length of personality inventory and the evaluation of a generalized personality interpretation. Journal of Personality Assessment 37(1): 83-85.

27. Burisch M (1984) You don't always get what you pay for: Measuring depression with short and simple versus long and sophisticated scales. Journal of Research in Personality 18(1): 81-98.

28. Burisch M (1997) Test length and validity revisited. European Journal of Personality 11(4): 303-315.

29. Baumeister RF, Bratslavsky E, Finkenauer C, Vohs KD (2001) Bad is stronger than good. Review of General Psychology 5(4): 323-370.

30. Kline P (2000) Handbook of psychological testing ( $2^{\text {nd }}$ edn.). Routledge, London, England.

31. Nunnally JC (1978) Psychometric theory (2 ${ }^{\text {nd }}$ edn.). Jossey-Bass, San Francisco, California USA 
The Arabic form of (ASOC)

$$
\text { الجنس: ذئر / أنثى (ضع دائرة) }
$$

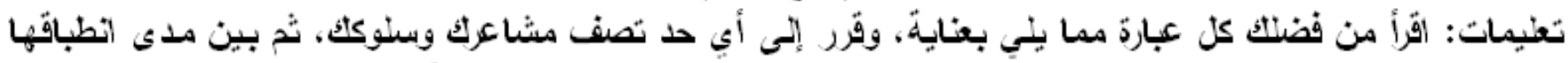

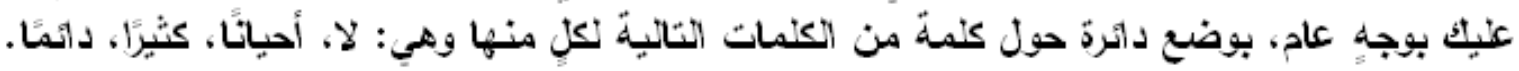

\begin{tabular}{|c|c|c|c|c|}
\hline دائمًا & كثيرًا & أحبانًا & $\bar{y}$ & 1-أنا سعيد بأسلوب حباتي. \\
\hline 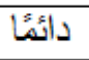 & كثيرًا & آحبِانًا & V & 2-أَتأكد عدة مرات قبل النوم من إغلاق الأبواب. \\
\hline دائمًا & كثيرًا & أحيانًا & $\bar{y}$ & 3-لّح على ذهني عبارة أو كلمة معينة. . \\
\hline دائمًا & كثيرًا & أحيانًا & $\bar{y}$ & 4-آحب النظام الدقيقُ. \\
\hline دائمًا & كثيرًا & أحبانًا & ע & 5-أثُعر بالتَفاؤل تجاه المنتُقبل. \\
\hline دائمًا & كثيرًا & آحِيانًا & $\bar{y}$ & 6-تُشغلني أثتياء تَافهة وتسبطر على تفكيري. \\
\hline دائمًا & كثيرًا & آحبانًا & $\bar{y}$ & 7-أقوم بالغسل والتنظيف بشكل وسواسيي. \\
\hline دائمًا & كثيرًا & آحِيًاً & $\bar{y}$ & 8-مشكلتي مراجعة الأشياء بصورة منكررة. \\
\hline دائمًا & كثيرًا & آحِيانًا & $\bar{y}$ & 9-أقُوم بعملية عد الأشياء غير الهامة. \\
\hline دائمًا & كثيرًا & أحِيانًا & $\bar{y}$ & 10-تَضغط على ذهني أفكار منكرةة. \\
\hline دائمًا & كثيرًا & أحِيانًا & $\bar{y}$ & 11-أحب جمع أثياء كثيرة والاحتفاظ بها. \\
\hline دائمًا & كثيرًا & آحبانًا & $\mathrm{y}$ & 12 -تبدو لي الحياة جميلة. \\
\hline دائمًا & كثيرًا & آحبِانًا & $\mathrm{y}$ & 13-أفكر في أشياء قبيحة بحيث لا يمكن التحدث عنها. \\
\hline دائمًا & كثيرًا & آحِيانًا & $\mathrm{y}$ & 14 كتسبطر عليَ أفكار تافهة وتظل تضايقنّي عدة أيام. \\
\hline دائمًا & كثيرًا & أحيانًا & $\bar{y}$ & 15-أضطر إلى تكرار نفس الأفعال كاللمس والعد أو الغبلي. \\
\hline دائمًا & كثيرًا & آحِيًاًا & $\bar{\gamma}$ & 16-لديّ صعوبةُ في اتخاذ القرارات. \\
\hline دائمًا & كثيرًا & أحِيانًا & y & 17-أنا راضي عن نفسي. \\
\hline دائمًا & كثيرًا & أحِيانًا & y & 18-أهتح بالتفاصبل الصغيرة. \\
\hline دائمًا & كثيرًا & أَحِانًا & $\bar{\gamma}$ & 19-أنا شخص موسوس. \\
\hline دائمًا & كثيرًا & أحيانًا & $\bar{y}$ & 20-شُعر بالراحة والاطمئنان. \\
\hline دائمًا & كثيرًا & أحيانًا & y & 21 أَجمع أثشياء لا أحتّاج إليها. \\
\hline دائمًا & كثيرًا & أحبانًا & $\mathrm{y}$ & 22 أثُشعر بأنني مجبر على فعل أشياء معينة. \\
\hline دائمًا & كثيرًا & آحبانًا & $\bar{y}$ & 23-جِب أن أفعل الأشياء مرات كثيرة للتأكد من أنها دقيقةَ. \\
\hline دائمًا & كثيرًا & أحيانًا & $\bar{\gamma}$ & 24-أغسل بداي مرات كثيرة أو لفترة أطول من اللازم. \\
\hline دائمًا & كثيرًا & أحِيانًا & $y$ & 25-رأرع الأبواب، والنوافذ، والأدراج بشكل منكرر · \\
\hline
\end{tabular}




\section{(c) (i) \\ This work is licensed under Creative Commons Attribution 4.0 License}

To Submit Your Article Click Here:

Submit Article

DOI: $10.32474 / 0 J N B D .2018 .01 .000109$

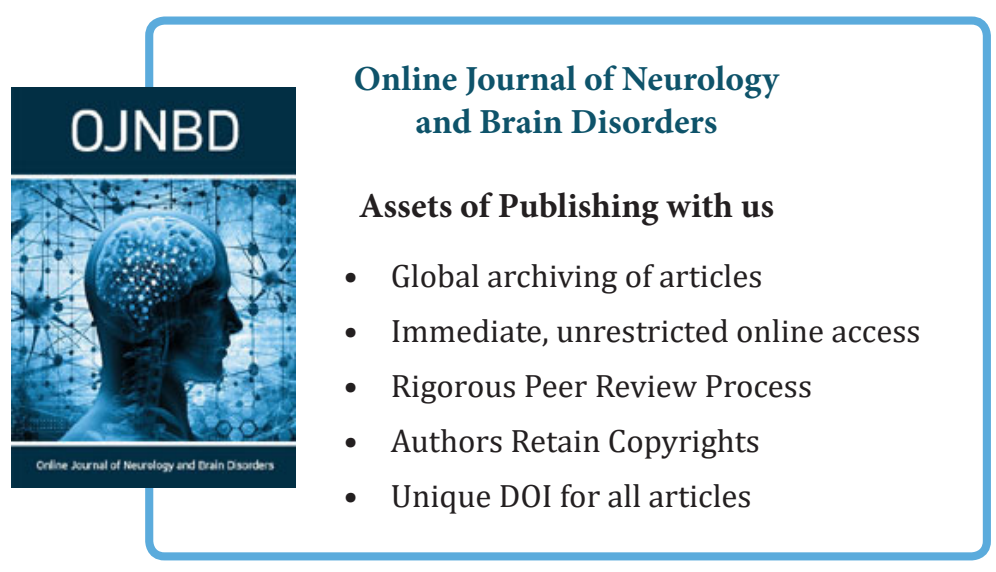

